\section{Chediak-Higashi Syndrome and Premature Exfoliation of Primary Teeth}

\author{
Karla Mayra Rezende ${ }^{1}$, Alfredo Hiram Carrillo Canela ${ }^{2}$, Adriana Oliveira Lira
}

Ortega ${ }^{1}$, Claudia Tintel ${ }^{2}$, Marcelo Bönecker ${ }^{1}$

The Chediak-Higashi syndrome (CHS) is a rare hereditary fatal disease, if not treated. These changes are associated with various diseases and syndromes that mainly cause periodontal disease and thus the premature loss of teeth. This paper describes the monitoring of premature loss of primary teeth that began when the child was 5 years old. On presentation his teeth were mobile and there was a history of gingival bleeding. Panoramic radiography revealed generalized and severe bone loss, and the teeth showed no bony support enough for their stability. Blood test was ordered to assess the overall health of the child and giant cells with cytoplasmic granules were found, confirming the diagnosis of CHS. The management of periodontal disease focused on the control of infection and bacterial plaque by mechanical and chemical methods.
1Department of Pediatric Dentistry, School of Dentistry, USP - University of São Paulo, São Paulo, SP, Brazil 2Department of Pediatric Dentistry, Universidad Autonoma de Asuncion, Asuncion, Paraguay

Correspondence : Profa. Dra. Karla Mayra Rezende Av. Prof. Lineu Prestes, 2227, Cidade Universitária, 05508-000 São Paulo, SP, Brazil.

Tel/Fax: +55-11-3091-7835. e-mail karla.rezende@usp.br

Key Words: Chediak Higashi, systemic disease, oral health.

\section{Introduction}

Chediak-higashi syndrome (CHS), a rare childhood hereditary disorder caused by mutations in the lysosomal trafficking regulator gene (LYST), can be lethal if left untreated (1). It results in impaired function of multiple body cells and systems. The alterations in the immune system may be located at cellular and/or humoral level. In this context, lymphocytes play a key role in immune function and the congenital or acquired absence of one or more cell lines gives rise to diseases that may be proven fatal (2). Alterations in the humoral immune system, fundamentally affecting the immunoglobulins, generate periodontal disease when the humoral disorder in turn affects other systems such as cellular immunity or the metabolic system. Therefore, the alteration of these two systems is the principal mechanism underlying periodontal disease mediated by immunoglobulins (3).

It is known that in this syndrome, the neutrophils and monocytes are defective in chemotaxis, bacterial killing and degranulation and are hyperactive in their phagocytic capacity (4). History of recurrent infections since early childhood is a common finding in these patients (5).

Beginning as infants, children with CHS suffer from recurrent infections, most commonly involving the skin and respiratory systems. Typical processes including periorbital cellulitis, otitis media, pneumonia, pyoderma, abscesses, sinus infections, and dental caries (6). Staphylococcus aureus and beta-hemolytic Streptococcus are the predominant organisms, but gram negative organisms, Candida and Aspergillus are also important pathogens (7).

The alteration of the periodontal tissues may be a primary consequence of such systemic alterations or a secondary effect, causing periodontal disease to progress without any apparent underlying cause, or alternatively maintaining or incrementing the severity of a previously established local condition (8).

The periodontal condition in CHS manifests as early onset periodontitis with premature exfoliation of both dentitions. The patterns of bone resorption may be local or generalized, and are related to the gingival inflammation (8). In addition to this situation, lysosomal alterations and defective chemotaxis in neutrophils give rise to very aggressive periodontitis which tends to be recurrent and it is refractory to antibiotic treatment (9).

This paper present the clinical features of a pediatric patient with Chediak-Higashi focusing on the dental manifestations and recommended treatment.

\section{Case Report}

Consent forms for examination and authorization of image disclosure for scientific publication were properly signed by the legal guardian of the child, according to protocols of the 1996 resolution of the National Health Council of the Ministry of Health (Brazil).

The patient of this case is a 10 -year-old boy with intense gingival inflammation, bone resorption, attachment loss, and severe mobility of all primary teeth. The premature loss of teeth was the reason for the family in seeking specialized dental care.

Evaluation of the family history did not reveal significant endogamy, with parents and grandparents not being consanguineous (first degree cousins). A questionnaire was used to collect data about all relatives.

On examination the child had a slight hypochromia on skin (Fig. 1). Review of medical history and dental examinations revealed no caries history. Periodontal 
examination revealed tooth mobility, severe gingival inflammation, especially around the upper and lower incisors, and generalized and severe bone destruction. Diastemas were present between most teeth and the gingival tissues were swollen and easily bled on provocation (Fig. 2). The severity and extent of periodontal lesions aroused suspicion of an underlying medical condition.

Panoramic radiography aids monitoring the development of periodontal disease. It could be observed noted general improvement of alveolar bone loss and many teeth seem not to support remnant bone (Fig. 3).

Medical pediatric examination was performed and included inflammatory and immune cell test. The patient displayed decreased pigmentation of his hair and eyes. Blood examination revealed the presence of large granules in the cytoplasm of erythrocytes. The granules were single or multiple and varied in size from moderate to massive. The massive intracellular inclusions are pathologic hallmarks of CHS and helped confirming the diagnosis (Fig. 4)

The prognosis for the child's oral health was unfavorable, and it was necessary to extract the mandibular right and left first molars due to severe mobility of teeth causing inflammation and pain on chewing. Despite having normal platelet and appropriate clotting time, the child had extensive bleeding, which was controlled. The management of periodontal disease focused primarily on the control of infection and bacterial plaque by using mechanical (professional dental prophylaxis) and chemical (0.12\% chlorhexidine mouthrinses) methods as part of a bimonthly periodontal therapy support program.

\section{Discussion}

A healthy smile is one way of developing interpersonal relationships and self-esteem. So, the premature loss of deciduous teeth is not normal and may be an important sign for the diagnosis of systemic health.

CHS is a rare (approximately 200 cases reported worldwide) autosomal recessive multi-system disease caused by mutations in the lysosomal trafficking regulator gene (LYST/CHS1) $(10,11)$. Thus, it is more frequent when there is inbreeding, which did not occur in our case.

According to the literature, the clinical findings such as hair color and hematologic abnormalities are typical features of this syndrome. Silvery gray hair provides clue to underlying immunodeficiency and thus find when associated with fever, pancytopenia and systemic involvement should alert the clinician to consider CHS since early diagnosis and treatment can improve the prognosis $(12,13)$. In the present case, this did not happen because the hair color was slightly lighter. This syndrome was made through dental findings. The child came to the dental office at age of 7 years by presenting early loss of teeth, pain when chewing and periodontal disease. Although with a panoramic radiograph made when the child was 5 years old. Because early loss of primary teeth and gingival inflammation that the patient had is not very common, we had decided on complete health examination of this child.

The periodontal condition manifested as early onset periodontitis with premature exfoliation of both dentition. The patterns of bone resorption may be local or generalized, and are related to the gingival inflammation (9).

Understanding the pathogenesis of periodontitis in CHS
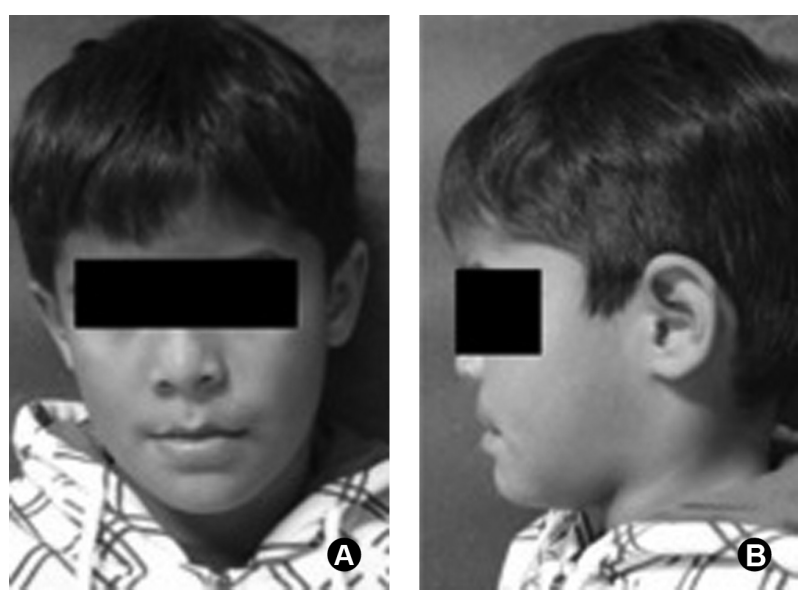

Figure 1. Physical examination of the patient (A, B). Hypochromic slight on skin.
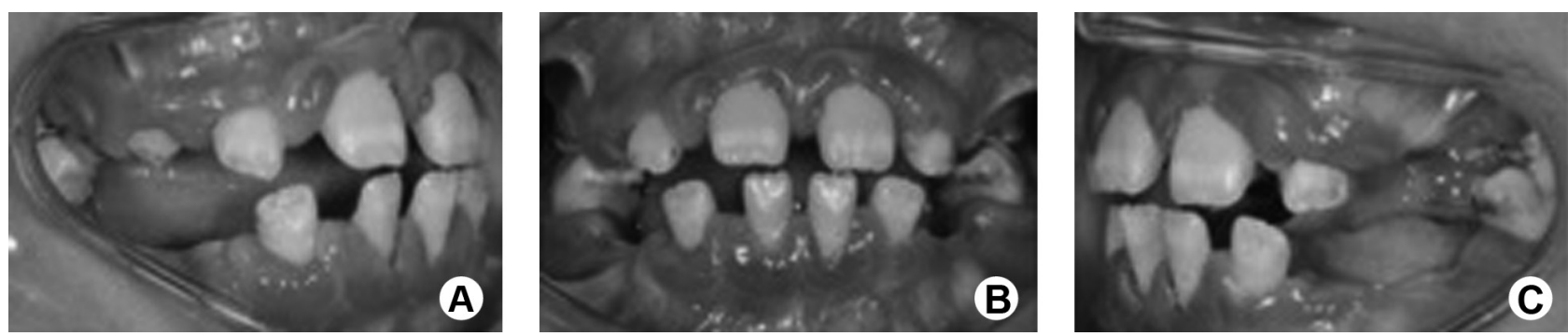

Figure 2. Clinical images showing misplaced teeth, generalized swelling of gingival margins, loss of interdental papillae and heavy accumulation of dental plaque. 
may help improve our understanding of the pathogenesis of periodontitis in the general population (14). In periodontal disease, it happens an immune/inflammatory response in the gingival tissues (15). The immune/inflammatory response involves the participation of several cells such as neutrophils, lymphocytes and NK cells as well as and biological mediators (16). Because of mass immune cell dysfunction, CHS causes the bacterial cells to gain access to inside the gingival tissues (14). Premature exfoliation of primary teeth is an important diagnostic event warranting urgent investigation. Most conditions presented with early
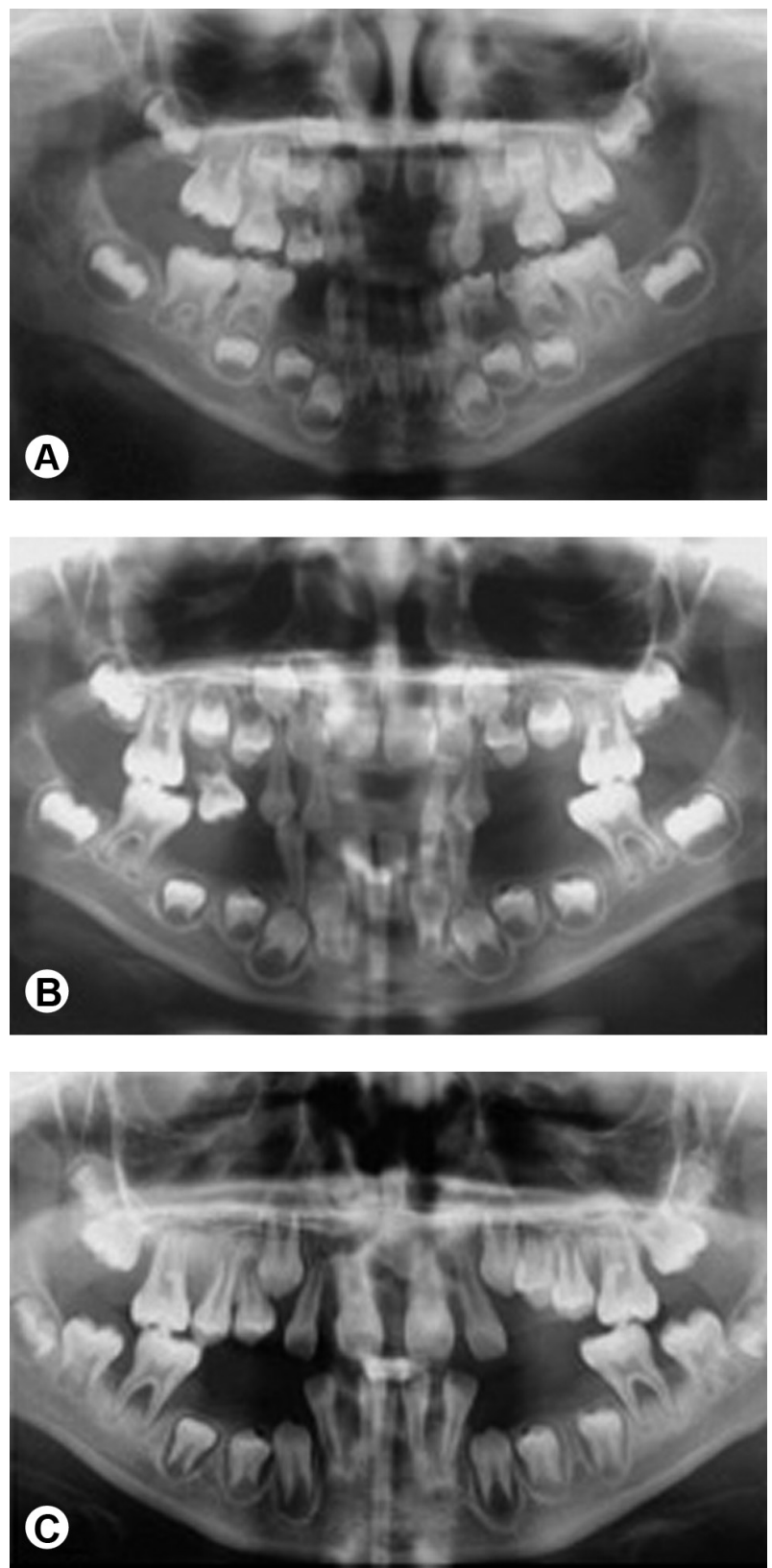

Figure 3. Panoramic x-ray showing generalized extensive alveolar bone loss. A: Child was 5 years old. B: showing absence of deciduous teeth and bone loss. Child was 7 years old. C: showing bone loss at the furcation area in molars. Child was 10 years old. loss of teeth are serious and in some cases fatal.

Our knowledge of periodontal abnormalities in CHS patients is derived mainly from a few case reports. Perhaps, because the disease is lethal and life expectancy is usually short before the age of 10 years old due to infections, bleeding or organ failure (1).These observations emphasize the importance of a robust and dynamic immune cell response in defending the periodontium.

Physically, the phenotypic aspects were normal. The patient displayed decreased pigmentation of his hair and eyes (partial albinism). Blood examination revealed the presence of large granules in the cytoplasm of lymphocytes and neutrophils. The granules were single or multiple and varied in size from moderate to massive. The massive intracellular inclusions are pathologic hallmarks of $\mathrm{CHS}$ and helped to confirm the diagnosis. The histological feature of the syndrome is the presence of giant granules within various cells of the body. These granules include vesicles such as lysosomes, melanosomes, cytolytic granules and platelet dense bodies. The fact that all of these organelles are affected suggests a common origin or regulation mechanism in their biogenesis (11). Investigators have used cell biology and biochemical techniques to try to determine the function of the CHS1/LYST/Beige protein. Some cell types have unique organelles (i.e. secretory granules, melanosomes) that perform specific functions. Because these organelles are believed to be of the same lineage as lysosomes, investigators have studied cells with these specific organelles.

The knowledge of this syndrome in a multidisciplinary team involving laboratory and clinical management to treat the disease is of paramount importance to restore masticatory function. Genetic disorders, which result in modification of periodontal structure or immune or

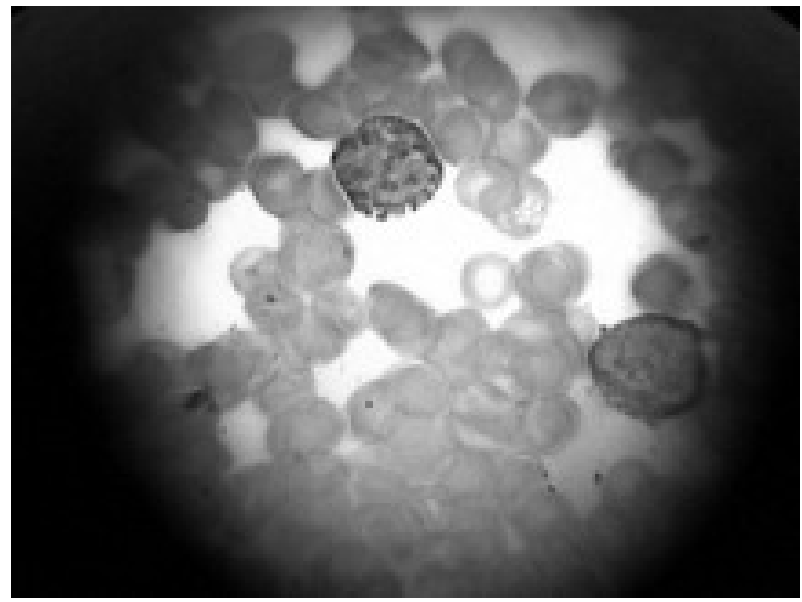

Figure 4: Blood smear showing large erythrocytes - pathognomonic sign (100x). 
inflammatory responses can result in gross periodontal destruction in the affected person (17). Therefore, this syndrome is associated with significant periodontal problems, including severe gingival inflammation and advanced alveolar bone loss (14).

The best treatment option for CHS is not well defined and it is still controversial (18). Parenteral vitamin $C$ administered in the stable phase may normalize neutrophils bactericidal activity $(19,20)$. The management of periodontal disease in this patient was based on the control of infection and on the amount of bacterial plaque (8). Treatment with bone marrow transplantation may be helpful in correcting neutrophil dysfunction in some patients (21). The clinical follow up includes bimonthly periodontal therapy support. This includes professional dental cleaning and rinsing with $0.12 \%$ chlorhexidine. In the present case, due to mobility of teeth, it was decided to perform the extraction of both mandibular first molars, as described in other reports $(8,22,23)$.

The child is so far under follow-up care what has improved periodontal health.

\section{Resumo \\ A sindrome de Chediak-Higashi (CHS) é uma doença rara hereditária e fatal se não for tratada. Estas alterações estão associadas com várias doençase sindromes que, principalmente, causa a doença periodontal assim como perda prematura de dentes. Este artigo descreve o monitoramento de perda prematura de dentes deciduos, que começou quando a criança tinha 05 \\ 4 anos. Na apresentação os dentes estavam com mobilidade e apresentava sangramento gengival. As radiografias panorâmicas revelaram perda óssea generalizada e grave, e os dentes sem suporte ósseo suficiente para a sua estabilidade. Foi realizada o exame de sangue para avaliar a saúde geral da criança no qual foi encontrado células gigantes com grânulos citoplasmáticos, confirmando o diagnóstico de CHS. 0 tratamento da doença periodontal por meio de métodos mecânicos e químicos são necessários para controle da infecção e da placa bacteriana.}

\section{Reference}

1. Rihani $\mathrm{R}$, Barbar $\mathrm{M}$, Fagih $\mathrm{N}$, Halalsheh $\mathrm{H}$, Hussein $\mathrm{AA}$, Al-Zaben $\mathrm{AH}$, et al.. Unrelated cord blood transplantation can restore hematologic and immunologic functions in patients with Chediak-Higashi syndrome. Pediatr Transplant 2012;16:E99-E105.

2. Perez LA, Al-Shammari KF, Giannobile WV, Wang HL. Treatment of periodontal disease in a patient with Ehlers-Danlos syndrome. A case report and literature review. J Periodontol 2002;73:564-70.

3. Wilton JM, Griffiths GS, Curtis MA, Maiden MF, Gillett IR, Wilson DT, et al. Detection of high-risk groups and individuals for periodontal diseases. Systemic predisposition and markers of general health. J Clin Periodontol 1988;15:339-346.

4. Newburger PE. Disorders of neutrophil number and function. Hematology 2006:104-10.
5. Meyle J, Gonzales JR. Influences of systemic diseases on periodontitis in children and adolescents. Periodontology 2000 2001;26:92-112.

6. Introne W, Boissy RE, Gahl WA. Clinical, molecular, and cell biological aspects of Chediak-Higashi syndrome. Mol Genet Metab 1999;68:283303.

7. Blume RS, Wolff SM. The Chediak-Higashi syndrome: studies in four patients and a review of the literature. Medicine 1972;51:247-280.

8. Nualart-Grollmus ZC, Morales-Chávez MC, Silvestre-Donat FJ.Periodontal disease associated to systemic genetic disorders Med Oral Patol Oral Cir Bucal 2007;12:E211-E215.

9. Izumi Y, Sugiyama S, Shinozuka O, Yamazaki T, Ohyama T, Ishikawa I. Defective neutrophil chemotaxis in Down's syndrome patients and its relationship to periodontal destruction. J Periodontol 1989;60:238242.

10. Lloyd-Evans E, Platt FM. Lysosomal $\mathrm{Ca}(2+)$ homeostasis: role in pathogenesis of lysosomal storage diseases. Cell calcium. 2011;50(2):200-5.

11. Shiflett SL, Kaplan J, Ward DM. Chediak-Higashi Syndrome: a rare disorder of lysosomes and lysosome related organelles. Pigment Cell Res 2002;15:251-257.

12. Sahana $M$, Sacchidanand $S$, Hiremagalore $R$, Asha G. Silvery grey hair: clue to diagnose immunodeficiency. Int J Trichology. 2012;4:83-85.

13. Inamadar AC, Palit A. Silvery hair with bronze-tan in a child: A case of Elejalde disease. Indian J Dermatol Venereol Leprol 2007;73:417-419.

14. Khocht A, Viera-Negron YE, Ameri A, Abdelsayed R. Periodontitis associated with Chediak-Higashi syndrome in a young African American male. Journal of the Int Acad Periodontol 2010;12:49-55.

15. Page RC. The role of inflammatory mediators in the pathogenesis of periodontal disease. J Periodontal Res 1991;26:230-42.

16. Hajishengallis $E$, Hajishengallis G. Neutrophil homeostasis and periodontal health in children and adults. J Dent Res 2013 [Epub ahead of Print. DOI: 10.1177/0022034513507956].

17. Kinane DF, Marshall GJ. Periodontal manifestations of systemic disease. Aust Dent J 2001;46:2-12.

18. Sparber-Sauer M, Honig M, Schulz AS, zur Stadt U, Schutz C, Debatin $K M$, et al. Patients with early relapse of primary hemophagocytic syndromes or with persistent CNS involvement may benefit from immediate hematopoietic stem cell transplantation. Bone Marrow Transplant 2009;44:333-338.

19. Nargund AR, Madhumathi DS, Premalatha CS, Rao CR, Appaji L, Lakshmidevi V. Accelerated phase of chediak higashi syndrome mimicking lymphoma--a case report. J Pediatr Hematol Oncol 2010;32:e223-e226.

20. Kanjanapongkul S. Chediak-Higashi syndrome: report of a case with uncommon presentation and review literature. J Med Assoc Thai 2006;89:541-544.

21. Trigg ME, Schugar R. Chediak-Higashi syndrome: hematopoietic chimerism corrects genetic defect. Bone Marrow Transplant 2001;27:1211-1213.

22. Shibutani T, Gen K, Shibata M, Horiguchi Y, Kondo N, Iwayama Y. Longterm follow-up of periodontitis in a patient with Chediak-Higashi syndrome. A case report. J Periodontol 2000;71:1024-1028.

23. Hamilton RE, Jr., Giansanti JS. The Chediak-Higashi syndrome. Report of a case and review of the literature. Oral Surg Oral Med Oral Pathol 1974;37:754-761. 